\title{
YIELD LOSS AND ECONOMIC THRESHOLDS OF YELLOW NUTSEDGE IN IRRIGATED RICE IN FUNCTION OF CULTIVARS
}

\author{
PERDAS DE PRODUTIVIDADE E NÍVEIS DE DANO ECONÔMICO DE TIRIRICA- \\ AMARELA EM ARROZ IRRIGADO EM FUNÇÃO DE CULTIVARES
}

\author{
Dirceu AgOSTINeTTO; Nixon da Rosa WESTENDORFF²; André da Rosa ULGUIM³; \\ Marcos André NOHATTO ${ }^{4}$; Luis Antonio de AVILA \\ 1. Professor, Doutor, Universidade Federal de Pelotas - UFPel, Pelotas, RS, Brasil. dirceu.agostinetto@pq.cnpq.br; 2. Engenheiro \\ Agrônomo, Mestre em Fitossanidade, Universidade Federal de Pelotas - UFPel, Pelotas, RS, Brasil; 3. Engenheiro Agrônomo, Doutor \\ em Fitossanidade, Pesquisador do Instituto Rio-grandense do arroz - IRGA, Cachoeirinha, RS, Brasil; 4. Professor, Doutor em \\ Fitossanidade. Universidade Estadual de Santa Catarina - UDESC, Lages, SC, Brasil; 5. Professor, PhD em Agronomia, Universidade \\ Federal de Pelotas - UFPel. Pelotas, RS, Brasil.
}

\begin{abstract}
Weeds cause reduction in the rice yield. Little is known about the competitive ability of yellow nutsedge (Cyperus esculentus) with rice and the extent of the economic threshold (ET). The aim of this study was to determine the fit of the regression model to estimate hyperbolic yield losses and ET of yellow nutsedge in rice due to the cycle of cultivars (BRS Querência - Early cycle and IRGA 424 - mid cycle). For this, a field study of competition in the agricultural year 2010/11 was conducted. Yield losses and ET of yellow nutsedge in rice crop is function on the competitive ability of rice cultivar used. The use of rice cultivar with early cycle, BRS Querência, increases the ETs of weed in rice crops compared to the use of IRGA 424, mid-cycle. The hyperbola satisfactorily estimated yield losses that yellow nutsedge causes in rice crops. The explanatory variable, population of yellow nutsedge, was the best fitted to the model. Increases in yield, price paid for rice and control efficiency promoted by the herbicide and decreased cost of weed control, promote ET reduction in yellow nutsedge in rice crops, justifying the adoption of control measures of smaller populations of the weed.
\end{abstract}

KEYWORDS: Cyperus esculentus. Oryza sativa L.. Mathematical simulation. weed.

\section{INTRODUCTION}

Rice is the most consumed cereal worldwide, and the second most cultivated after corn, occupying an average area of 153.4 million hectares over the last decade. Brazil is the world's 9th largest producer and the largest producer outside Asia (FAO, 2012). Weeds can be be hosts for pests and decrease the market value of the cultivated area; in addition, the competition for environmental resources, imposed by weeds to crops, it one of the factors that cause a decrease in yield (GALON et al. 2007).

One of the species of sedges, the yellow nutsedge (Cyperus esculentus) is better adapted to humid lowlands, being its spread almost exclusively vegetative, hindering their control and interfering directly or indirectly on the yield of rice (BUZSÁKI et al. 2008).

One way to reduce losses caused by yellow nutsedge in rice crops includes the use of cultivars with greater competitive ability and differentiated management practices (BALBINOT JUNIOR et al. 2003; FLECK et al. 2004). Features such as early emergence and establishment, plant vigor, increased leaf expansion rate, rapid canopy development, greater plant height, early cycle and increase in root size, have shown a direct influence on the competitive ability of cultivars (TIRONI et al. 2009).

By simulating competition, empirical mathematical models such as the derivative of the rectangular hyperbola (COUSENS, 1985) can predict loss of yield at initial phases for certain situations and, therefore, the reduction of the final crop yield (AGOSTINETTO et al. 2005). The models quantify, through explanatory variables such as plant population, shoot dry matter and ground cover, the relationship between crop yield loss and final weed infestation. Accordingly, studies have been conducted to predict losses caused by weeds in several crops of economic interest, including rice (AGOSTINETTO et al. 2005; AGOSTINETTO et al. 2007; GALON et al. 2007).

The present study hypothesizes that the rice cultivar BRS Querência (early cycle) has greater competitive ability against the competition with yellow nutsedge compared with cultivar IRGA 424 (mid-cycle), due to the higher speed of development and occupation of the niche and the data generated by the study will fit the nonlinear regression model derived from the rectangular hyperbola.

Thus, the objectives of the study were to quantify yield losses of rice cultivars (BRS 
Querência - early cycle and IRGA 424 - mid-cycle) in competition with different population levels of yellow nutsedge, as well as estimate the degree of data fits to the hyperbolic regression model.

\section{MATERIAL AND METHODS}

To meet the objectives of the research, a study was conducted in the field, in the agricultural year 2010/11. The experimental design was completely randomized, with a replicate. The different populations of yellow nutsedge were used as replicates, providing the variance needed to perform statistical analyzes by the hyperbolic model proposed by Cousens (1985).

Treatments were arranged in a factorial design, in which the factor rice cultivars had two levels: an early-cycle cultivar (BRS Querência) and a mid-cycle cultivar (IRGA 424), and the factor of populations of competitor plant (nutsedge yellow) had twelve levels for each level of the factor cultivar. For BRS Querência, the levels of competitor weed were the following: 0 (four clean controls), 64, 140, 144, 172, 180, 200, 280, 368, 808, 924, and 1,084 yellow nutsedge plants $\mathrm{m}^{-}$ ${ }^{2}$ while for IRGA 424 , levels of the competitor weed were: 0 (four clean controls), 56, 84, 184, 244, 264, $276,360,592,604,668$, and 740 yellow nutsedg plants $\mathrm{m}^{-2}$. The variables analyzed in the study, presumably associated with loss of yield experienced by rice cultivars at 25 DAE were weed population (WP), shoot dry weight of the weed (SDW), and ground cover by the weed (GC). Weed populations in both studies were established at seven DAE of the crop (Dec. 10, 2010).

The area chosen for conducting the studies was naturally infested with yellow nutsedge. Thus, the populations of the weed were adjusted for the constant population levels of the treatments. Each experimental unit had an area of $7.65 \mathrm{~m}^{2}(5.0 \mathrm{~m} \mathrm{x}$ $1.53 \mathrm{~m}$ ) with nine rice lines spaced at $0.17 \mathrm{~m}$. The area was prepared using conventional tillage with plowing, harrowing and leveling. Broadcast fertilization was performed as needed by the crop, informed by soil analysis. The soil of the experimental area is classified as Planossolo Hidromórfico Eutrófico solódico, belonging to the mapping unit Pelotas (EMBRAPA, 2009).

The used rice cultivars were sown on Nov.24, 2010, with a nine-row seeder, seed density of $103 \mathrm{~kg} \mathrm{ha}^{-1}$, which provided that the final population of approximately 380 viable rice plants $\mathrm{m}^{-2}$. Crop emergence occurred on Dec. 3, 2010. Nitrogen top-dressing application $\left(72 \mathrm{~kg} \mathrm{~N} \mathrm{ha}^{-1}\right)$ was split into two periods: half rate was administered immediately before irrigation (Nov. 17, 2010) and half rate at panicle initiation of rice. Irrigation of the experimental area was held on Nov. 17, 2010, i.e. 14 DAE.

The surplus specimen of the target yellow nutsedge populations in the studies and also of other weeds that were established in experimental units were controlled by herbicides at $7 \mathrm{DAE}$. For the control of species of the family Poaceae, the herbicide cyalofop-butyl $\left(\right.$ Clincher $\left.^{\circledR}\right)$ was used at a rate of $1.5 \mathrm{~L} \mathrm{~h}^{-1}$, together with vegetable oil (Veget $\left.\mathrm{Oil}^{\circledR}\right)$ at a rate of $1 \mathrm{~L} \mathrm{ha}^{-1}$. For Cyperaceae plants that exceeded the desired population levels and other broad-leaf species, the herbicide bentazon (600 Basagran $^{\circledR}$ ) was used at a rate of $1.6 \mathrm{~L} \mathrm{ha}^{-1}$ plus mineral oil $\left(\right.$ Assist $\left.^{\circledR}\right)$ at a rate of $0.5 \mathrm{v} / \mathrm{v} \%$. For the establishment of yellow nutsedge populations, the plants were previously protected with plastic cups or brown paper bags, so they were not affected by the herbicide bentazon.

The variables analyzed at 25 DAE were: weed population (WP), shoot dry weight (SDW) and ground cover (GC). To determine SDW, the plants were collected in an area of $0.25 \mathrm{~m}^{2}(0.5 \mathrm{~m} \times 0.5 \mathrm{~m})$, and they were subsequently dried in an oven at a constant temperature of $60{ }^{\circ} \mathrm{C}$ until constant weight, and then they were weighed. Quantification of WP was performed by counting the specimen present in two areas of $0.25 \mathrm{~m}^{2}(0.5 \mathrm{mx} 0.5 \mathrm{~m})$ in each experimental unit. GC was determined by visual assessment using the averages of two raters.

To determine grain yield, the area of each experimental unit $\left(3 \mathrm{~m}^{2}\right)$ was harvested according to the maturity of each cultivar, when grain moisture content was about $22 \%$.

After the grains were weighed, their moisture was determined, the values corrected for $13 \%$ humidity content. Data for grain yield were used to calculate percentage loss compared to the portions maintained without infestation (control) according to the equation:

$$
\begin{gathered}
\operatorname{Loss}(\%)=[(\mathrm{Ra}-\mathrm{Rb}) / \mathrm{Ra}] \times 100 \\
(\text { equation } 1)
\end{gathered}
$$

where: $\mathrm{Ra}$ and $\mathrm{Rb}$ : crop yields with or without the presence of $C$. esculentus, respectively.

The values of shoot dry weight $\left(\mathrm{g} \mathrm{m}^{-2}\right)$ and ground cover $(\%)$ were previously multiplied by 100 , thus avoiding the need to correct these values in the model (ASKEW; WILCUT, 2001).

The relationships between percentage of rice yield loss (Yl), according to the explanatory variables WP, SDW and GC were calculated separately for each cultivar, using the nonlinear 
regression model derived from the rectangular hyperbola, as proposed by Cousens (1985):

$\mathrm{Yl}=[i x X /(1+(i / a) \times X)]$

(equation 2)

where: $\mathrm{Yl}=$ yield loss $(\%), \mathrm{X}=$ explanatory variables WP, SDW or GC; $\mathrm{i}$ and $a=$ yield loss (\%) per unit of yellow nutsedge when the value of the variable approached zero or when it tends to infinity, respectively.

The data were fitted to the model by nonlinear regression using a statistical computer program. For this procedure was based on the Gauss-Newton method, which, by successive iterations, estimates parameter values at which the sum of the squared deviations of observations, in relation to the set values, is minimal (RATKOWSKY, 1983). The value of the F statistic $(p \leq 0.05)$ was used as the criterion to analyze the data for the model. The acceptance criteria of data fits to the model was based on the highest coefficient of determination $\left(\mathrm{R}^{2}\right)$ and the lowest residual mean square (RMS).

The calculation of the economic threshold (ET) used the estimates of the parameter $i$, obtained from equation 2 (COUSENS, 1985), and the equation adapted by Lindquist and Kropff (1996):

$\mathrm{ET}=[C c /(P \times R \times(i / 100) \times(H / 100))]$ (equation 3 )

where: $\mathrm{ET}=$ economic threshold (yellow nutsedge plants $\left.\mathrm{m}^{-2}\right), \quad C c=$ cost control (herbicide and application in dollars ha ${ }^{-1}$ ) $P=$ price of rice (US\$ kg ${ }^{1}$ grain); $R=$ rice grain yield $\left(\mathrm{kg} \mathrm{ha}^{-1}\right), i=$ loss (\%) of rice yield per unit of weed when the population level approaches zero and $H=$ level of herbicide efficiency $(\%)$.

For variables cc, P, $R$ and $H$ (Equation 3) three values were estimated. Thus, for cost control $\left(C_{C}\right)$ the average value of US\$ $54.3 \mathrm{ha}^{-1}$ was considered $\left(1.6 \mathrm{~L} \mathrm{ha}^{-1}\right.$ of commercial product Basagran $^{\circledR} 600+$ mineral oil Assist ${ }^{\circledR}$ at $0.5 \% \mathrm{v} / \mathrm{v}+$ the cost of aerial application $\mathrm{ha}^{-1}$ of the product in Pelotas/Rio Grande do Sul in the agricultural year 2010/11). The minimum and maximum costs were changed by $\pm 30 \%$ compared to the average cost. Prices (P) were obtained from the lowest (US\$ 7.50), the average (US\$ 12.40) and the highest (US\$21.00) amount paid for the $50 \mathrm{~kg}$ bag of paddy rice in Rio Grande do Sul over the last 10 years (IRGA, 2013a). The yield of rice (R) was based on the lowest $\left(5,630 \mathrm{~kg} \mathrm{ha}^{-1}\right)$, the average $\left(6,665 \mathrm{~kg} \mathrm{ha}^{-}\right.$ $\left.{ }^{1}\right)$ and the highest rice yield $\left(7,700 \mathrm{~kg} \mathrm{ha}^{-1}\right)$ obtained in the Rio Gande do Sul over the last 10 years (IRGA, 2013b). The values of efficiency of the herbicide control $(\mathrm{H})$ were established in the order of 80,90 and $100 \%$ control, where $80 \%$ was the minimum acceptable level of weed control promoted by the herbicide (SOSBAI, 2010). The calculations of ET were based on intermediate values of the variables related to equation 3 that were not targeted by the calculation.

\section{RESULTS AND DISCUSSION}

The values of the $F$ statistic showed significance for all variables analyzed and data were properly fitted to the regression model derived from the rectangular hyperbola, evidenced by the relatively high coefficients of determination $\left(\mathrm{R}^{2}\right)$ and the relatively low values of residual mean squares (Figure 1).

For all variables, the results showed that the estimated values for the parameter $i$ were lower for BRS Querência (early cycle) compared to IRGA 424 (mid-cycle). This demonstrates that reducing the cycle of the cultivar increases its competitive ability, which may be due to greater initial development, resulting in premature niche occupation and premature use of growth resources (Figure 1).

Considering parameter $i$ of the model, which was the index used to compare the relative competitiveness between species (SWINTON et al. 1994), it was observed, on the average parameter values for the analyzed variables, that cultivar BRS Querência was about $50 \%$ more competitive than IRGA 424 (Figure 1). Thus, the cultivar with early vegetative cycle demonstrated greater competitive ability than the weed studied, when compared with the medium maturity cultivar.

In addition to faster occupation of the ecological niche, the difference in competitive ability between rice cultivars may be due to morphological and physiological characteristics, such as height and dry weight accumulation (BALBINOT JUNIOR et al. 2003), and/or due to the standard error in the estimate of the parameter $i$ of the model, because of the variability normally found in field experiments (DIELEMAN et al. 1995). This may hinder the correct estimate of loss of crop yield under low weed populations (GALON et al. 2007). 

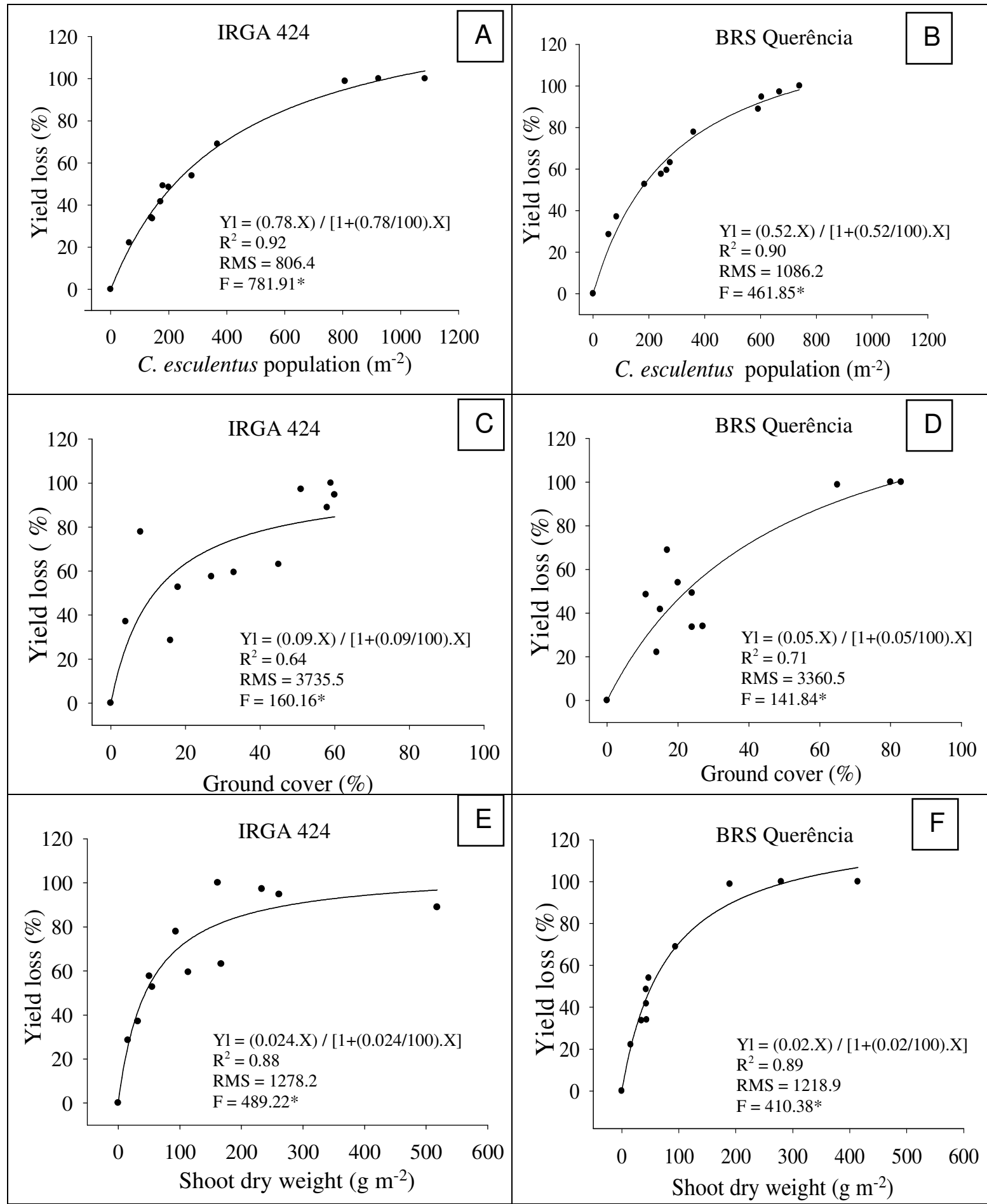

Figure 1. Yield loss (Yl) of rice cultivars IRGA 424 and BRS Querência, depending on weed population level, estimated ground cover and shoots dry weight of Cyperus esculentus at 25 days after emergence (DAE) 2010/11, Pelotas/RS. R²: Coefficient of determination; RMS: Residual mean square; * Significant at $5 \%$ probability.

Different values for the parameter $i$ between cultivars with different vegetative cycles, were also observed in studies using the same model. Corroborating the results obtained, the average parameter $i$ for rice cultivars IRGA 417 and IRGA 416 (early cycle) were about 130\% lower than that of BRS Fronteira (mid-cycle), when subjected to competition against barnyardgrass (GALON et al. 2007). Also, IRGA 417 showed an increase of $28 \%$ in competitive ability, compared with BR-IRGA 409 (mid-cycle), when in competition with cultivar EEA-406, a red rice simulating cultivar (AGOSTINETTO et al. 2005). 
For cultivar IRGA 424, the parameter $i$ showed yield losses of $0.78,0.09$, and $0.024 \%$ per unit area for the variables WP, GC and SDW, respectively (Figure 1A, 1C and 1E), while for BRS Querência, the parameter $i$ had grain yield losses per unit area of approximately 0.52, 0.05, and $0.02 \%$ (Figure 1B, 1D and $1 \mathrm{~F}$ ), considering the same order of the variables. Cultivars from different vegetative cycles can behave independently when interspecific competition and, thus, the result in yield can also be different (FLECK et al. 2004). The low values obtained for the parameter $i$ show low competitiveness of yellow nutsedge compared to other weed species such as barnyardgrass (GALON et al. 2007) or red rice (AGOSTINETTO et al. 2005). Competing with barnyardgrass, there were losses per unit area of 4.71 and $13.67 \%$ for the early-cycle cultivar IRGA 417 and the mid-cycle cultivar BRS Fronteira, respectively (GALON et al. 2007). In contrast, when in competition against red rice, early-cycle cultivar IRGA 417 experienced losses of $4.17 \%$ per unit of weed (AGOSTINETTO et al. 2005).

The values of parameter $i$ obtained by the hyperbolic regression model (COUSENS, 1985) were 0.52 and 0.78 for the cultivars BRS Querência and IRGA 424, respectively, considering the explanatory variable WP adjust by the best data fit to the regression model used in the study (Table 1). Thus, comparing the competitive ability of rice cultivars from different vegetative cycles with yellow nutsedge and, based on this parameter (SWINTON et al. 1994), it was found that BRS Querência (early cycle) showed greater competitive ability than the IRGA 424 (mid-cycle), regardless of the explanatory variables used for simulation of ET (Figures 2A, 2B, 2C and 2D).

Tabel 1. Yield loss ( $\mathrm{Yl})$ of rice depending on the population of Cyperus esculentus $\left(\mathrm{m}^{-2}\right)$ at 25 days after crop emergence (DAE) and two rice cultivars from different vegetative cycles, 2010/11, Pelotas/RS.

\begin{tabular}{cccccc}
\hline Cultivars & Cycle & Yield loss $(\boldsymbol{\%})^{\mathbf{1}}$ & $\mathbf{R}^{\mathbf{2}}$ & F* $^{*}$ & RMS \\
\hline BRS Querência & Early & $(0.52 . X) /[1+(0.52 / 100) . X]$ & 0.90 & 461.85 & 1086.2 \\
IRGA 424 & Mid & $(0.78 . X) /[1+(0.78 / 100) . X]$ & 0.92 & 781.91 & 806.4 \\
\hline
\end{tabular}

${ }^{\mathrm{T}}$ Value obtained through the regression model of hyperbolic (Cousens, 1985). $\mathrm{R}^{2}$ : Coefficient of determination; * Significant at 5\% probability; RMS: Residual mean square.

Early-cycle cultivars such as BRS Querência have faster initial development and leaf area accumulation and, therefore, more cleverly intercept light, reducing the incidence of solar energy to neighboring plants (BALBINOT JUNIOR et al. 2003). The rapid initial development of BRS Querência possibly favored higher interception of sunlight, increasing its competitive ability against the presence of yellow nutsedge. Thus, cultivars that have this feature are usually more skilled competitors (BALBINOT JUNIOR et al. 2003).

The competitive ability of rice cultivars may be influenced by intrinsic characteristics of each cultivar, but it is rather variable among genotypes (BALBINOT JUNIOR et al. 2003; FLECK et al., 2004). Consequently, management, mainly chemical management, should be carefully performed for weed control, due to the greater competitive ability provided by these intrinsic characteristics, thus decreasing the potential environmental and economic impacts stemming from herbicide use (AGOSTINETTO et al. 2007; GALON et al. 2007).

When each variable was analyzed separately, on the average of the two cultivars, variation of about $87 \%$ in ET was observed for the variable cost control (Figure 2A). TL values, for both cultivars, ranged from 2.8 to 11.6 yellow nutsedge plants $\mathrm{m}^{-2}$, depending on the cycle. These values were obtained when simulating the price paid to the harvested product (Figure 2B), which arises from the wide range of prices paid over the last ten crop harvests (IRGA, 2013a). For barnyardgrass, variation in $\mathrm{ET}$, on the average of cultivars IRGA 417 (early cycle) and BRS Fronteira (mid-cycle) was approximately $67 \%$, considering the same variable (GALON et al. 2007).

Variations in the order of $180 \%$ were obtained in ET for variable price paid for rice (Figure 2B). For the same variable, variations of about $87 \%$ in ET were observed for the average of cultivars IRGA 417 (early cycle) and BR-IRGA 409 (mid-cycle) in competition against the red rice simulating cultivar EEA 406, when spaced at $15 \mathrm{~cm}$ (AGOSTINETTO et al. 2005). Also for the same variable, ET ranged $135 \%$, on average, for the cultivars IRGA 417 and BRS Fronteira (mid-cycle), when in competition against barnyardgrass (GALON et al. 2007). 


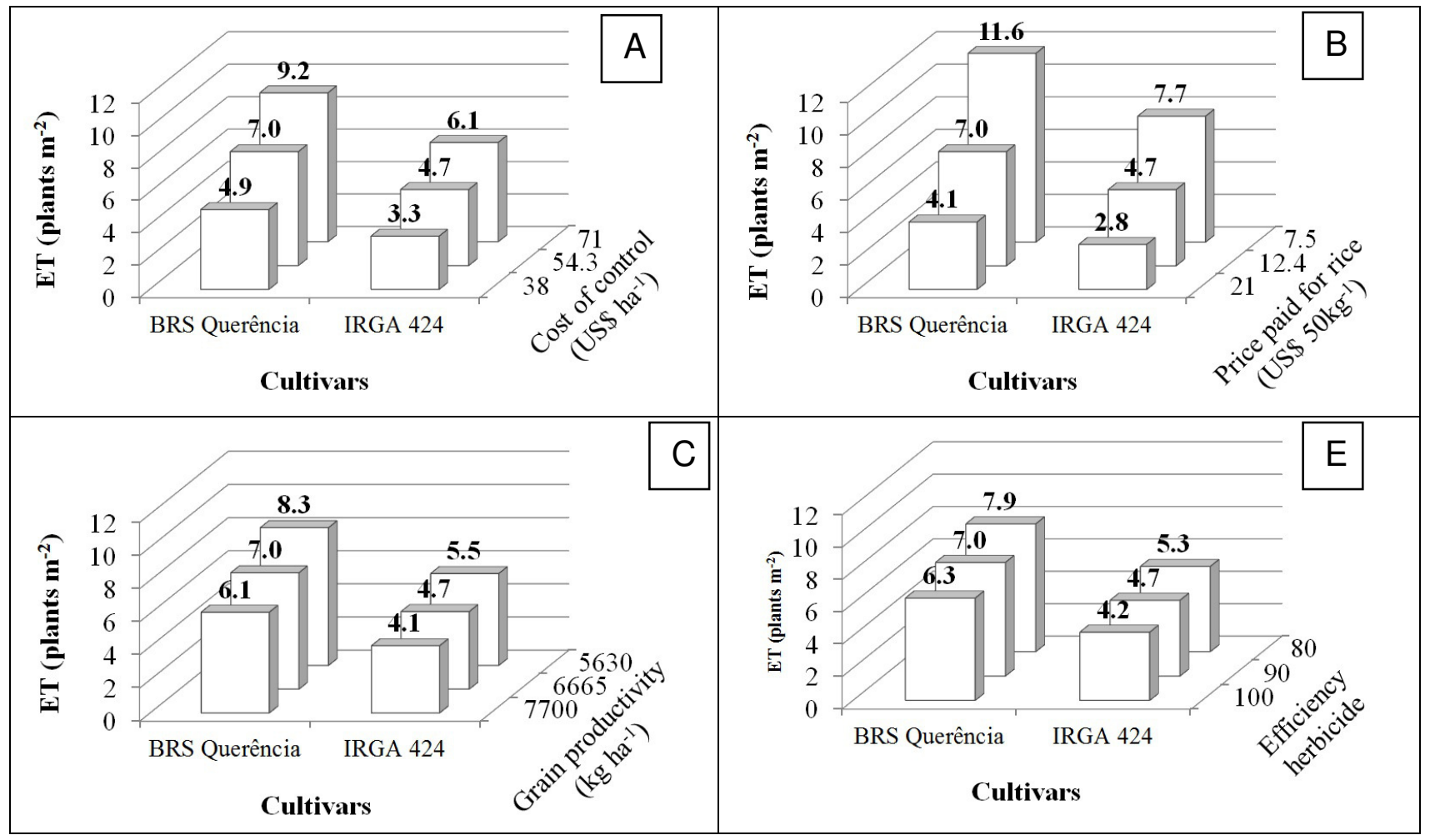

Figure 2. Economic threshold (ET) of Cyperus esculentus for two rice cultivars depending on the cost control of weed, price paid for $50 \mathrm{~kg}$ of paddy rice, grain yield and efficiency of control herbicide, 2010/11, Pelotas/RS.

ET values for yield ranged around $37 \%$ on the average of the two cultivars tested (Figure 1C). For barnyardgrass, there was approximately $50 \%$ of variation for the average of cultivars BRS 417 and IRGA Fronteira for the same variable (GALON et al. 2007), while for the red rice simulating cultivar EEA 406, ET varied around $127 \%$ for the average of the cultivars IRGA 417 and BR-IRGA 409, considering yield and spacing of $15 \mathrm{~cm}$ between rows (AGOSTINETTO et al. 2005).

Considering the variable herbicide effectiveness, variation of about $25 \%$ could be observed for ET on the average of the cultivars (Figure 1D). Similar variations for the same variable were observed in ET of Barnyardgrass for the average of cultivars IRGA 417 and BRS Fronteira (GALON et al. 2007). For this variable, the ET of the red rice simulating cultivar EEA 406 ranged around $29 \%$ for the average of cultivars BR-IRGA 417 and IRGA 409, when they were spaced at $15 \mathrm{~cm}$ (AGOSTINETTO et al. 2005).

It is important to realize, considering the factors that determine ET values (Figures 2A, 2B, $2 \mathrm{C}$ and $2 \mathrm{D}$ ), that these values ranged between 5.4 and 9.2, on average, for the rice cultivar BRS Querência, and from 3.6 to 6.2, on average, for rice cultivar IRGA 424. Thus, in the latter, ET values were approximately $33 \%$ lower than those simulated for the early-cycle cultivar, making control of yellow nutsedge a priority for IRGA 424.

Considering the intermediate values of each variable, the decreasing order of magnitude of the yellow nutsedge ET that will support the decision making of control are: price paid for rice $>$ cost of weed control $>$ grain yield of the crop $>$ efficiency control herbicide. Therefore, it can be inferred that for the conditions studied, the price paid for rice represented the greatest impact on decision making control and control efficiency provided by the herbicide, less impact. However, the variables price paid for the product and cost control, is difficult to be changed by farmers, leaving them to provide appropriate management practices to maintain yield and efficiency promoted by herbicide control are maximized.

Thus, considering the variables studied, the simulations showed that the greater the amount paid for rice, grain yield and effectiveness of herbicide control, the lower the ET values will be, and the early adoption of yellow nutsedge control will compensate more, while for greater cost control of yellow nutsedge, the greater the ET values, and the use of control measures will compensate later.

When the variables are evaluated together, on the averages of the cultivars, there was a variation of $49 \%$ in ET among them (Figures 2A, 2B, 2C and 2D). Similarly, early-cycle rice cultivars 
were more skilled competitors, when compared to mid-cycle rice cultivars (AGOSTINETTO et al. 2005; GALON et al. 2007). Thus, the management of yellow nutsedge by chemical control must be differentiated depending on the competitive potential of the cultivar, because it affects the total production cost and environmental impact through the use of herbicides. The quest to reduce the use of herbicides or use them rationally tends to minimize the consequences of their undesirable impacts (RIZZARDI; FLECK, 2004). In the same sense, the competition by more skilled cultivars can minimize the use of herbicides and therefore the selection pressure, a process that tends to favor the emergence of herbicide-resistant specimen in weed populations (NORSWORTHY et al. 2012).

\section{CONCLUSIONS}

The rice cultivar BRS Querência, early cycle, presents greater competitive ability yellow nutsedge than the rice cultivar of mid cycle IRGA 424.

The variable yellow nutsedge population is the best fit to the model, although the variable dry matter of shoots can be used to estimate yield losses in rice when in competition with the weed.

The presence of one plant yellow nutsedge $\mathrm{m}^{-2}$ causes yield loss of crop ranging from 0.52 to
$0.78 \%$ for BRS Querência and IRGA 424, respectively, considering the variable population weed the best fit data to the hyperbolic model.

The weed showed low competitiveness with the rice crop, requiring at least considering the variable best fit, three units of weed $\mathrm{m}^{-2}$, so that the control is justified.

The hyperbolic regression model appropriately estimates of crop yield losses in rice due to differences in growing season of the rice cultivars.

The economic threshold (ET) yellow nutsedge in rice vary depending on the competitive ability of rice cultivar used.

The use of the cultivar BRS Querência increases the ET when compared to the use of mid cycle cultivar IRGA 424.

Increases in grain yield, price paid for rice and control efficiency promoted by the herbicide and the decreasing cost of weed control, causes a reduction in the ET yellow nutsedge in rice crop, justifying the adoption of measures smaller population under control of the weed.

\section{ACKNOWLEDGMENT}

To $\mathrm{CNPq} / \mathrm{Brazil}$ for providing a research grant to the first author.

RESUMO: As Plantas daninhas causam redução da produtividade do arroz. Pouco se conhece sobre a habilidade competitiva da tiririca-amarela (Cyperus esculentus) com o arroz e qual seu nível de dano na cultura (NDE). O objetivo desse estudo foi determinar o ajuste do modelo hiperbólico estimando perdas de produtividade e NDEs de tiriricaamarela no arroz em função do ciclo das cultivares (BRS Querência - ciclo precoce e IRGA 424 - ciclo médio). Para tal, foi conduzido estudo de competição a campo no ano agrícola 2010/11. Perdas de produtividade e NDE de tiririca-amarela no arroz variam em função da habilidade competitiva da cultivar utilizada. O uso da cultivar de ciclo precoce, BRS Querência, aumenta os NDE da infestante no arroz quando comparada ao uso da IRGA 424, de ciclo médio. A hipérbole estima satisfatoriamente as perdas de produtividade que a tiririca-amarela causa à cultura do arroz. A variável explicativa população de tiririca-amarela é a que mais se ajustou ao modelo. Aumentos da produtividade, do preço pago pelo arroz e da eficiência de controle promovido pelo herbicida e a diminuição do custo de controle da planta daninha, promovem redução nos NDE de tiririca-amarela no arroz, justificando adoção de medidas de controle sob menor população da planta daninha.

PALAVRAS-CHAVE: Cyperus esculentus. Oryza sativa L. Simulação Matemática. Planta daninha.

\section{REFERENCES}

AGOSTINETTO, D.; GALON, L.; MORAES, P. V. D.; TIRONI, S. P.; DAL MAGRO, T.; VIGNOLO, G. K. Interferência de capim-arroz (Echinochloa spp.) na cultura do arroz irrigado (Oryza sativa) em função da época de irrigação. Planta Daninha, v. 25, n. 4, p. 689-696, 2007. http://dx.doi.org/10.1590/S010083582007000400005 
AGOSTINETTO, D.; FLECK, N. G; RIZZARDI, M. A.; BALBINOT JUNIOR, A. A. Dano econômico como critério na decisão sobre manejo de genótipos de arroz concorrentes em arroz irrigado. Pesquisa Agropecuária Brasileira, v. 40, n. 1, p. 1-9, 2005. http://dx.doi.org/10.1590/S0100-204X2005000100001

ASKEW, S. D.; WILCUT, J. W. Tropic croton interference in cotton. Weed Science, v. 49, n. 2, p. 184-189, 2001. http://dx.doi.org/10.1614/0043-1745(2001)049[0184:TCIIC]2.0.CO;2

BALBINOT JUNIOR, A. A.; FLECK, N. G.; BARBOSA NETO, J. F.; RIZZARDI, M. A. Características de plantas de arroz e a habilidade competitiva com plantas daninhas. Planta Daninha, v. 21, n. 2, p. 165-174, 2003. http://dx.doi.org/10.1590/S0100-83582003000200001

BUZSAKI, K.; KAZINCZI, G.; BERES, I.; LEHOCZKY, E. The allelopathic effect of yellow nutsedge (Cyperus esculentus) on cultivated plants and common ragweed (Ambrosia artemisiifolia L.). Journal of Plant Diseases and Protection, Supplement (21), p. 327-331, 2008.

COUSENS, R. D. An empirical model relating crop yield to weed and crop density and a statistical comparison whit other models. Journal of Agricultural Sciences, v. 105, n. 3, p. 513-521, 1985.

http://dx.doi.org/10.1017/S0021859600059396

DIELEMAN, A.; HAMILL, A. S.; WEISE, S. F.; SWANTON, C. J. Empirical models of pigweed (Amaranthus spp.) interference in soybean (Glycine max). Weed Science, v. 43, n. 4, p. 612-618, 1995.

EMBRAPA. Centro Nacional de Pesquisa de Solos. Sistema brasileiro de classificação de solos. 2.ed. Rio de Janeiro: Embrapa Solos, 2009. 412 p.

FAO. Food and Agriculture Organization of the United Nations. 2012. Production of cereals and share in world. Disponível em: <http://faostat.fao.org/site/339/default.aspx>. Acesso em: 20 jan. 2014.

FLECK, N. G.; AGOSTINETTO, D.; RIZZARDI, M. A.; BIANCHI, M. A.; MENEZES, V. G. Interferência de plantas concorrentes em arroz irrigado modificada por métodos culturais. Planta Daninha, v. 22, n. 1, p. 19-28, 2004. http://dx.doi.org/10.1590/S0100-83582004000100003

GALON, L; AGOSTINETTO, D.; MORAES, P. V. D.; DAL MAGRO, T.; PANOZZO, L. E.; BRANDOLT, R. R.; SANTOS, L. S. Níveis de dano econômico para decisão de controle de capim-arroz (Echinochloa spp.) em arroz irrigado (Oryza sativa). Planta Daninha, v. 25, n. 4, p. 709-718, 2007.

http://dx.doi.org/10.1590/S0100-83582007000400007

IRGA. Instituto Rio-grandense do Arroz. 2013a. Série histórica de preços de arroz em casca. Disponível em: <http://www3.irga.rs.gov.br/uploads/anexos/1371644498PRECOS_ARROZ_SERIE_HISTORICA_1975_casc a_DOLAR.pdf >. Acesso em: 30 set. 2013.

IRGA. Instituto Rio-grandense do Arroz. 2013b. Área e produção de arroz. Disponível em: <http://www.irga.rs.gov.br/upload/20131024101611producao_rs_e_brasil.pdf>. Acesso em: 30 set. 2013.

LINDQUIST, J. L.; KROPFF, M. J. Applications of an ecophysiological model for irrigated rice (Oryza sativa) - Echinochloa competition. Weed Science, v. 44, n. 1, p. 52-56, 1996.

NORSWORTHY, J. K.; WARD. S. M.; SHAW, D. R.; LLEWELLYN, R. S.; NICHOLS, R. L.; WEBSTER, T. M.; BRADLEY, K. W.; FRISVOLD, G.; POWLES, S. B.; BURGOS, N. R.; WITT, W. W.; BARRETT, M. Reducing the Risks of Herbicide Resistance: Best Management Practices and Recommendations. Weed Science, v. 1, n.spe., p. 31-62, 2012.

RATKOWSKY, D. A. Nonlinear regression modeling: a unified practical approach. New York: Marcel Dekker, 1983. p. 276. 
RIZZARDI, M. A.; FLECK, N. G. Métodos de quantificação da cobertura foliar da infestação de plantas daninhas e da cultura da soja. Ciência Rural, v. 34, n. 1, p. 13-18, 2004. http://dx.doi.org/10.1590/S010384782004000100003

SOSBAI. Arroz irrigado: recomendações técnicas da pesquisa para o sul do Brasil. Porto Alegre: Pallotti, 2010. 188p.

SWINTON, S. M.; BUHLER, D. D.; FORCELLA, F.; GUNSOLUS, J. L.; KING, R. P. Estimation of crop yield loss due to interference by multiple weed species. Weed Science, v. 42, n. 1, p. 103-109, 1994.

TIRONI, S. P.; GALON, L.; CONCENÇO, G.; FERREIRA, E. A.; SILVA, A. F.; ASPIAZÚ, I.; FERREIRA, F. A.; SILVA, A. A.; NOLDIN, J. A. Habilidade competitiva de plantas de arroz com biótipos de capim-arroz resistente ou suscetível ao quinclorac. Planta Daninha, v. 27, n. 2, p. 257-263, 2009.

http://dx.doi.org/10.1590/S0100-83582009000200007 